\title{
CHINA-PAKISTAN ECONOMIC CORRIDOR: A KEY TO REGIONAL CONNECTIVITY AND DEVELOPMENT
}

\author{
Rabia Shakir* \\ Jaweria Nehal $^{* *}$ \\ Suwaibah Qadri***
}

\begin{abstract}
Pak-China nexus has always been exemplary and phenomenal. Year 2015 is marked as the biggest milestone between these two all-weather friends. China Pakistan Economic Corridor (CPEC) is the key to the door that leads to the biggest ever trade activity that will be started from China and will be expanded to the middle-east, African and even some vibrant European markets. It is the biggest deal signed between Pakistan and any other country that promises the huge economic commotion. This corridor is basically a part of new phase of globalization where the economic cooperation between countries and regions define the future of the respective economies. Due to its great economic and geo-strategic importance, CPEC has acquired global attention and analysts from all over the world are holding different opinions on this substantial economic corridor between China and Pakistan. This paper is a brief overview of the intra-regional connectivity that CPEC ensures and its impact on socioeconomic development of the entire region. This study evaluates the growth of energy sector, infrastructure development and advancements in connectivity in terms of transportation and communication as a result of this mega project. It also describes the inter-regional coordination within the country that will strengthen area-to-area bonding that is important for the uniform economic progress so far. Once the things start to move on smoothly and smartly, there is no ambiguity that this project will turn out as the socioeconomic revolution, mainly for Pakistan, then for China and obviously for the other countries of the region as well.
\end{abstract}

Keywords: China Pakistan Economic Corridor, intra-regional, inter-regional, socioeconomic development

\section{Introduction}

Pak Chin dosti....wangwoye (May the bond between Pakistan and China never breaks) is the anthem that we have been listening since long. This everlasting relationship between the two neighbors has been passed through many stages of strategic to the economic cooperation. The irrevocably strategic, diplomatic, political and commercial relationship between these two countries have seldom witnessed any crests and troughs as it has always remained resilient enough. The idea of CPEC has a history as the dialogues of bridging Pakistan's deep water ports on Arabian Sea with Chinese Border began in

\footnotetext{
"RabiaShakir, Ph.D. Scholar \&Lecturer, Department of Economics, University of Karachi ** JaweriaNehal, M.Phil. Student, Applied Economics Research Centre, University of Karachi

${ }^{* * *}$ Suwaibah Qadri, Ph.D. Department of Political Science, University of Karachi
} 
1950s. The construction of Karakoram Highway and Gwadar in 2006 was a part of this notion. The formal talks on CPEC and its initial sketch were materialized in the Parvez Musharraf's era but could not progress on the grounds of political instability. Zardari's led, Pakistan People's Party's government proposed it again, although it was formally launched during Nawaz Sharif's led Pakistan Muslim League (Nawaz)'s government in $2015 .^{1}$

The China-Pakistan Economic corridor, commonly known as CPEC is the bystander of the finest friendly relationship between Pakistan and China. It is a fateful project under which a huge network of roads and highways, infrastructure and energy sector related construction is under progress, costing $\$ 46$ billion, invested by People's Republic of China in Pakistan. ${ }^{2}$ This project is often subjected as a strategic game changer for Pakistan's economy along with entire region.

CPEC is an extravagant extension of China's maestro ideology of One Belt, One Road. OBOR is a proposition objected to connect with different countries through road and railway network to revel in massive trade breaks. ${ }^{3}$ There are total 6 corridors that have to be built under OBOR stratagem of China from which CPEC is one of them. CPEC embraces a significant scope in China's $13^{\text {th }}$ five year plan. ${ }^{4}$

According to estimations, China imports $60 \%$ of the total oil of Middle-East countries. It has to use a longer route that costs China a huge amount of money and time. Excessive travelling costs and delivery time provide a major break to China's competitors in trade that may include Japan, USA etc. It hampers China's performance to compete in global market arena. ${ }^{5}$

This economic corridor is designed to connect Pakistan through its Gwadar Port to the autonomous region of Xinjiang in the North-West China through the huge road, highway and railway networks. It will also connect Pakistan to the fast growing and vibrant markets of Middle-East, Africa and Europe; and will generate enormous trade opportunities for the country.

CPEC divides into two routes, Eastern and Western, from Islamabad Motorway (M1)that connect Gwadar Port to Western region of China. The network of roads and highways through both the routes do not only connect Gwadar Port with China but also renovate the intramural road map of Pakistan. Using the CPEC route for its oil imports from

${ }^{1}$ Nelson, Jazib. The TFT guide to CPEC for incredibly smart people. September 02, 2016. $\mathrm{http} / / / \mathrm{www}$.thefridaytimes.com/tft/the-tft-guide-to-cpec-for-incredibly-smart-people/ (accessed September 26, 2016).

${ }^{2}$ Aneja, Atul. Xi comes calling to Pakistan, bearing gifts worth $\$ 45$ billion. April 18, 2015.

http://www.thehindu.com/news/international/xi-jinping-visit-to-pakistan-preview/article7114980.ece (accessed September 09, 2016)

${ }^{3}$ APP. CPEC made part of China's 13th 5-year development plan: Weidong. November 23, 2015.

http://www.pakistantoday.com.pk/2015/11/23/business/cpec-made-part-of-chinas-13th-5-year-developmentplan-weidong/ (accessed September 26, 2016)

${ }^{4}$ masood, Talat. China's landmark investments in Pakistan. April 21, 2015.

http://tribune.com.pk/story/873627/chinas-landmark-investments-in-pakistan/ (accessed September 26, 2016)

${ }^{5}$ Ebrahim, Zofeen T. China's new silk road: What's in it for Pakistan? April 20, 2015.

http://www.dawn.com/news/1177116 (accessed September 26, 2016) 
middle-east and for trade of other goods, China can save a huge chunk of time and money. This is the main reason for China to invest in a country like Pakistan that is already facing enormous challenges within country and on its border line too.

The significance of CPEC is remarkable as its impacts on development and growth of both the countries, Pakistan and China, will change the fate of entire region. However, it is widely debated that who will make more out of it. Its socioeconomic impacts on Pakistan have started to emerge with the generation of employment opportunities for its citizens though.

This project promises to spawn up to 700,000 direct jobs for the professionals, engineers, labors and other technical staff. Apart from generating employment opportunities, it will boost the business venture as well. The construction sector and firms related to it have already started to expand. There will be short run socioeconomic impacts on Pakistan's economy while the construction phase of this corridor in the first place. The long run impacts will begin to emerge on the time when the projects of early harvest projects and short term projects will be completed and functional.

This paper analyzes the capacity of CPEC and its impact on socioeconomic development of the region. This research evaluates the growth of energy sector, infrastructure development and advancements in connectivity in terms of transportation and communication. This study also answers why CPEC is considered to be a strategic game changer for the entire region.

The remaining portion of this paper comprises the following sections: Section 2 examines the geostrategic importance of this project. Section 3 briefly discusses the famous slogan "CPEC-A Game Changer" and the impact of CPEC on different regional actors is critically debated. Section 4 highlights the stance of the Unites States of America on CPEC. Section 5 is based on CPEC route analysis. In section 6 Inter-regional development and connectivity is discussed in detail. Section 7 concludes the study and provides some policy suggestions.

\section{Geostrategic Importance}

It is widely believed in the context of world politics that the geographic location of a country determines its due importance. Thus it is important for the countries of today's world to focus on economic cooperation with the countries that lie under the strongest regions with less complicated neighborhood conditions in order to progress fast in this era of globalization. China understands the importance of regional connectivity for that matter especially when it knows the future returns of this bonding. China Pakistan Economic Corridor is the sequel of the construction of the great Karakoram Highway that was completed in 1979 between Khunjerab Pass of Pakistan to the Kashgar border of China. It is believed that during the construction of this highway, many Chinese labors lost their lives most of which are buried in the Gilgit-Baltistan region of Pakistan.

Now here is the important point that needs to be raised that why this passion of China is so clearly evident that it is trying to make the best out of this friendship. The answer is 
obviously the Pakistan's geographic location and specially the wonderful facts about Gwadar Port. To extend this on a greater scale we must understand the following map:

FIGURE - 1

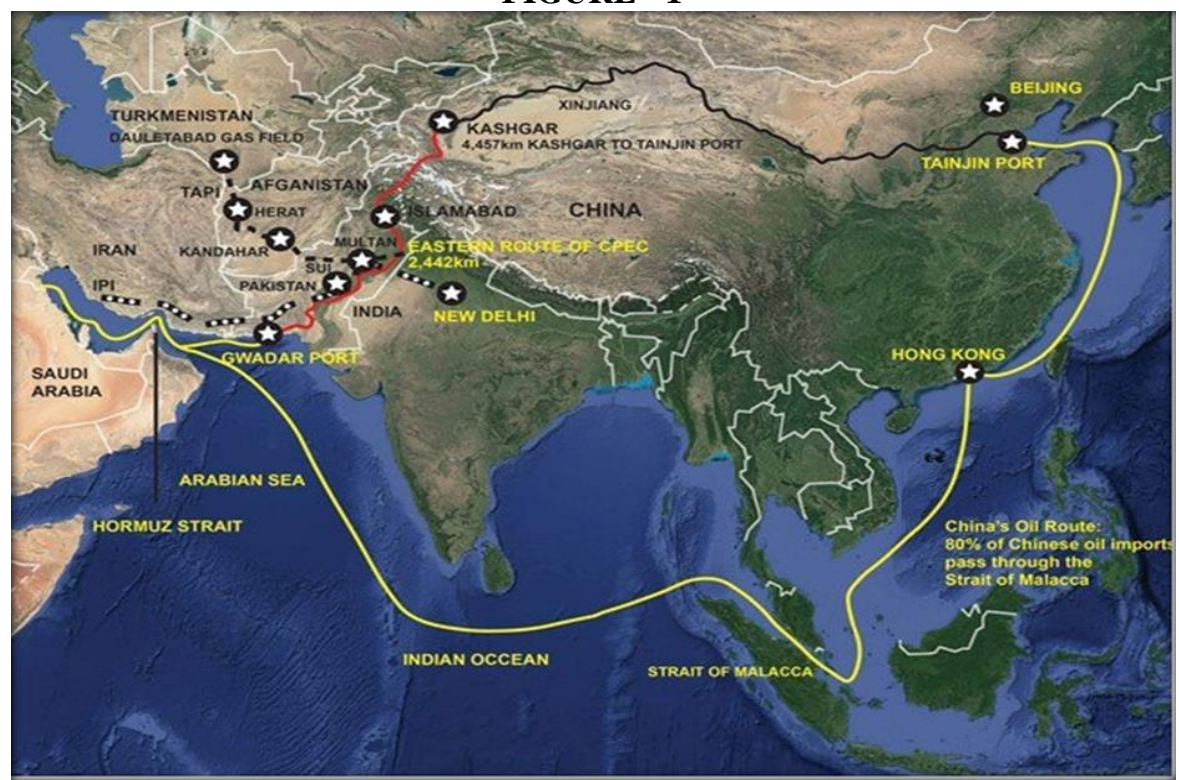

Source: The Friday Times ${ }^{6}$

China is an oil dependent country and it consumes about $10.3 \mathrm{mn}$ barrels oil per day. This oil is mainly imported from the middle-east countries. It is estimated that almost $80 \%$ of total oil imports of China are transported through the sea-route, crossing the straits of Malacca which is the yellow colored line in the map. Not only this route is the longer one and it takes many days for China to reach the middle-east but there is also the rivalry that goes on alongside the straits of Malacca. China finds it threatening enough for itself to use the controversial region. Moreover, it also has to cross India in its way that can also be critical if the already deteriorated relationships between Pakistan and India become worse. Keeping that in mind, it is quite obvious that China Pakistan Economic Corridor is a win-win situation for China as it does not need to pass through any controversial site in order to reach to the middle-east countries through the Gwadar Port of Pakistan.

Gwadar Port holds the prodigious significance in the CPEC. A port is mainly analyzed on the basis of two factors; its depth and its berth capacity (the number ships that can stopover at one time). In comparison with the other big and famous ports of the world, Gwadar is the best among all. Below is the chart showing the comparison between the depth and berth capacities of the seven biggest sea ports from which Gwadar seems to be on top with 28 meter depth and the berth capacity of 120 ships.

\footnotetext{
${ }^{6}$ Taken the image from this article: http://www.thefridaytimes.com/tft/the-tft-guide-to-cpec-for-incrediblysmart-people/
} 
Table -1

\begin{tabular}{|l|c|c|}
\hline \multicolumn{1}{|c|}{ PORT NAME } & DEPTH & BERTH CAPACITY \\
\hline Jabal Ali (UAE) & 9 Meters & 64 Ships \\
\hline Bandar Abbas (IRAN) & 9 Meters & 24 Ships \\
\hline Damam Port (SAUDI ARABIA) & 9 Meters & 39 Ships \\
\hline Doha Port (QATAR) & 11 Meters & 29 Ships \\
\hline Oman Salala (OMAN) & 10 Meters & 19 Ships \\
\hline Chabahar Port (IRAN) & 11 Meters & 10 Ships \\
\hline Gwadar Port (PAKISTAN) & $\mathbf{2 8 ~ M e t e r s ~}$ & $\mathbf{1 2 0}$ Ships \\
\hline
\end{tabular}

Source: Karachi Port Trust Official website

It is important from other side's perspective which is the matter of the province Xinjiang of China. Xinjiang is actually the region that is deprived and underdeveloped with a lot of potential but is the victim of mere ignorance. In Xinjiang, due to the depravity and worsen socioeconomic situation, a separatist movement is being run by Uyghur's Muslims. Thus, for the sake of its stability and to gratify the population currently abiding in Xinjiang, China is passionate about creating a socioeconomic framework for it. ${ }^{7}$ With the completion of CPEC, as it connects Xinjiang to Pakistan, the convoys will pass through this region. The ultimate impacts of this phenomenon will start making wonders for it will create the employment opportunities for the region. It will also become the reason for the development of infrastructure and other much needed facilities for the betterment of the people living there.

Likewise, it will also create opportunities for small businessmen/vendors, tourism sector; poor and deprived population of Pakistan who are waiting for some miracle to occur that can sustain their present and save the future of their next generations. CPEC is one such mega project in the history of China and Pakistan that will treat equally both the countries and its people to improve their living standards for that matter.

\section{CPEC - A Game Changer for the Region}

South-Asia is generally the most troubled part of the region in the context of political instability, economic underdevelopment, and peace situation. The countries that come under this region have been seeking for the much needed cooperation as in to make the situation better for their present and future. CPEC holds an immense power to create solid and undeniable impacts that can change the geostrategic and political status of all the regional actors including Pakistan and China. It is designed to change the fate of millions of people because of the fact that this mega project promises to accelerate the

${ }^{7}$ Cheema, Zumra Nawaz. Geostrategic importance of China-Pakistan Economic Corridor. May 2015, 2015. http://foreignpolicynews.org/2015/11/25/geostrategic-importance-of-china-pakistan-economic-corridor/ (accessed September 17, 2017) 
economic cooperation, technical support, fill communication gap, strengthen diplomatic relationships, improvising financial opportunities, small and medium level businesses, cultural diversity and other socioeconomic factors for those who are the part of the whole region. This is why it is famous as a strategic game changer for the entire region.

\section{Impact of CPEC on Regional Actors}

Among the huge network of roads, highways and motorways, one $265 \mathrm{~km}$ motorway is under the construction that will be connecting Kabul to Peshawar as a part of CPEC. This is how Afghanistan is directly associated with this project. Being an ally, it is going to benefit Afghanistan in several ways as this bridge between the two countries will open the trade opportunities for each other that will eventually affect the hampered economic conditions of Afghanistan due to war that is going on there. What is the need of time is to improve the foreign policy of Pakistan and have the open dialogue process with Afghanistan for the matter of stability and peace. Without peace, there is hardly any chance that the project will benefit on its full strength.

Iran, at first took it as a competition for it had been working on its Chabahar Port with the collaboration of India. Therefore CPEC had to face some resistance from Iran side but later on Iran realized the advantages of being part of this mega project. If Pakistan, with the great planning connects its border to Iran, it can be beneficial for Iran in a way that a Liquid Natural Gas (LNG) pipeline between China and Pakistan is a part of CPEC to import LNG from China. Now with the bridging of Pakistan and Iran, this can become the Iran-Pakistan pipeline as well. For China, it will be favorable in a way that it will become the shortest route for China to enter the great stock of Natural Gas in Iran.

The countries that lie in the Central Asian Republic are rich in oil reserves and other natural resources because of which all the other countries that are in dire need of clean and cheap energy pools take interest in these states. Uzbekistan, Kazakhstan and Turkmenistan hold a significant place in the whole scenario but the poor connectivity is the main hurdle in the economic cooperation with these countries. With the completion of CPEC this issue of connectivity will be resolved a big time and the transportation of the goods will become much easier than before.

Many of the regional actors are welcoming this project; however, some countries are not in favor with the idea of CPEC for their own reasons. In the economic growth of United Arab Emirates,ports play an important role. With the completion of Gwadar Port, Dubai Port will eventually have to lose around $70 \%$ of its business. Along with that, there are some political reasons behind that too. Because Pakistan rejected UAE's plea to send its troops as in to fight against Houthi rebels in Yemen along with the UAE and Saudi Arabian Army, UAE is trying to review its strategic relationships with Pakistan. Not realizing the fact that being a resistant to CPEC and making the nexus with India, just to oppose Pakistan will only leave UAE in a mere turmoil in long run.

Like China-Pakistan are considered to be all-weather friends, Pakistan-India are allweather opponents. Now apart from this rivalry, India has a lot more concerns over this project and the Indian Prime Minister on his visit to China, requested China to drop the 
idea which China refused to do so. This corridor promises to connect the different countries of the region including Iran, Afghanistan, Turkmenistan, Kazakhstan and Uzbekistan etc. India is concerned because she has no such connection with these countries like this. India finds itself to be in a trouble as economic coordination with these countries will become stronger for Pakistan. India knows the determination of China for this maestro project, thus, instead of directly exploiting CPEC, India is playing a controversial game as in to sabotage this project. India is also seeking for the different sort of strategic relationships with other countries so that it can compete with China and Pakistan on global market arena once if CPEC turns into reality. ${ }^{8}$

\section{The United States' Stance on CPEC}

United States being a world power can make a difference with its opposition for something. Unlike UAE and India, the US did not show up the resistance on an open front. It in fact issued the statements in favor of CPEC and also stressed on taking the neighborhood countries as a stakeholder in this project including Afghanistan where the US has been fighting a great war against terrorism. Although, there are chances in the future that CPEC has to go through some objections from the United States because of the great strategic importance that the Gwadar Port holds. It is quite obvious that Gwadar is going to be the head quarter for China because at the end, the initiator and the creator is China. This dominance on the world's best sea port will not be digested by some of the powerful countries like America easily. There are high chances of instability in world politics due to this project. No one will let prosper the undeveloped country like Pakistan to get involved in gigantic trade activity that CPEC assures. For that, Pakistan will need to reform its foreign policy and diplomatic strategy. Along with that, China will have to encompass its support to Pakistan in the process of redefining its foreign and diplomatic policies.

\section{Route Analysis}

CPEC is not just a road that is connecting China with Pakistan but it is basically a network of roads, railway lines and airports. China has the biggest advantage of saving time while reaching to the Persian Gulf as the journey of around 45 days will be shrunk to 10 days by connecting Gwadar to Kashgar, which is a fortiori of the strengthening regional connectivity through this project. ${ }^{9}$

China Pakistan Economic Corridor is 4,457km roadway from Tianjin Port, Beijing to Kashgar Border, Pakistan. The central route of China-Pakistan Economic Corridor is a roadway of $2,442 \mathrm{~km}$ from Kashgar to Gwadar Port. China can directly enter into middleeast countries through the deep water route of Arabian Sea from Gwadar Port. Hence, Gwadar Port has a protagonist status in this Project. It starts from Khunjerab pass after

\footnotetext{
${ }^{8}$ Butt, Dr Khalid Manzoor, and Anam Abid Butt. "Impact of CPEC on Regional and Extra-Regional Actors: Analysis OF Benefits and Challenges." Proceedings of International Conference on CPEC Held at GC University, Lahore on December 09-10, 2015. Lahore, 2015. 128-133

${ }^{9}$ Ahmed, Prof. Dr. Hafiz Zafar, and Samar Fatima. "CPEC 2015: A Review of Proposed Opportunities and Significance." Proceedings of International Conference on CPEC Held at GC University, Lahore on December 09-10, 2015. Lahore, 2015. 134-138
} 
crossing the Kashgar border. It then enters to the Abottabad district of Khyber Pakhtunkhwa. It then goes through Haripur and then enters to Hasan Abdal, from Hasan Abdal, it comes to the Burhan and then to the Islamabad Motorway (M1). From this point there are two possible routes through which the convoys can reach Gwadar Port, one is the Eastern Route and other is the Western Route.

FIGURE 2

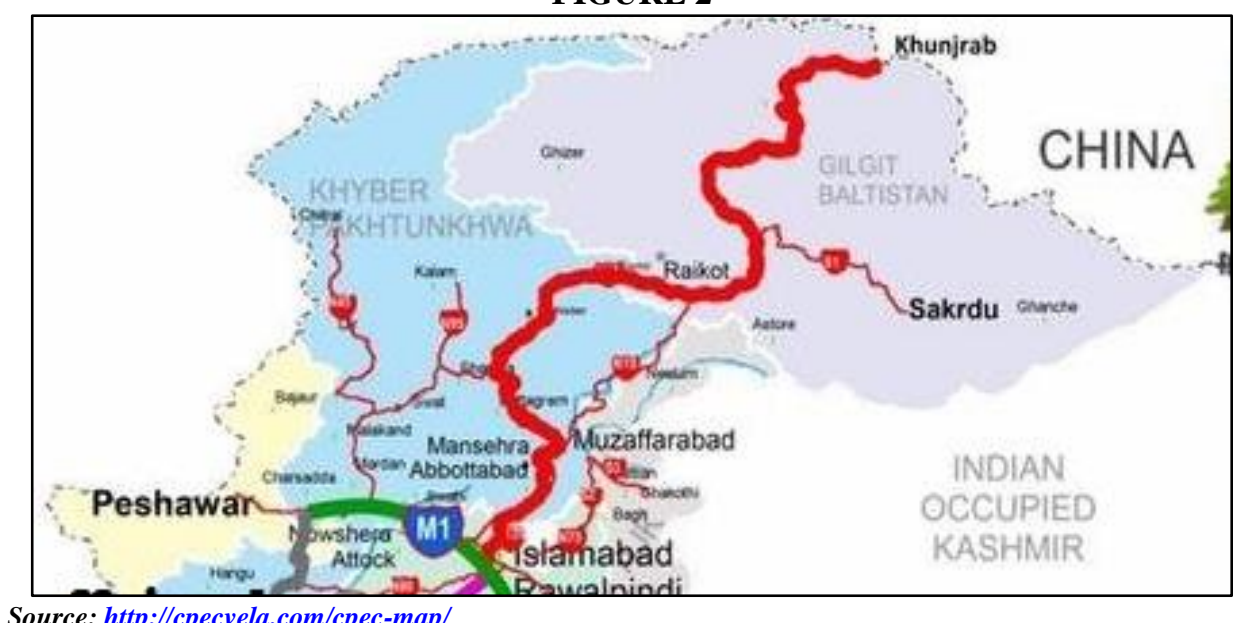

\section{Eastern Route}

Eastern route is $2,781 \mathrm{KM}$ long. It is the route on which most of the infrastructure is already available however, the improvement or upgrading is required. From M1, it is connected to Faisalabad Motorway. From M2 it is connected to Lahore-Karachi Motorway crossing Lahore, Sukkur, Multan, Hyderabad and Karachi. From Karachi, Makran Coastal Highway is already there to reach Gwadar Port. 
FIGURE 3

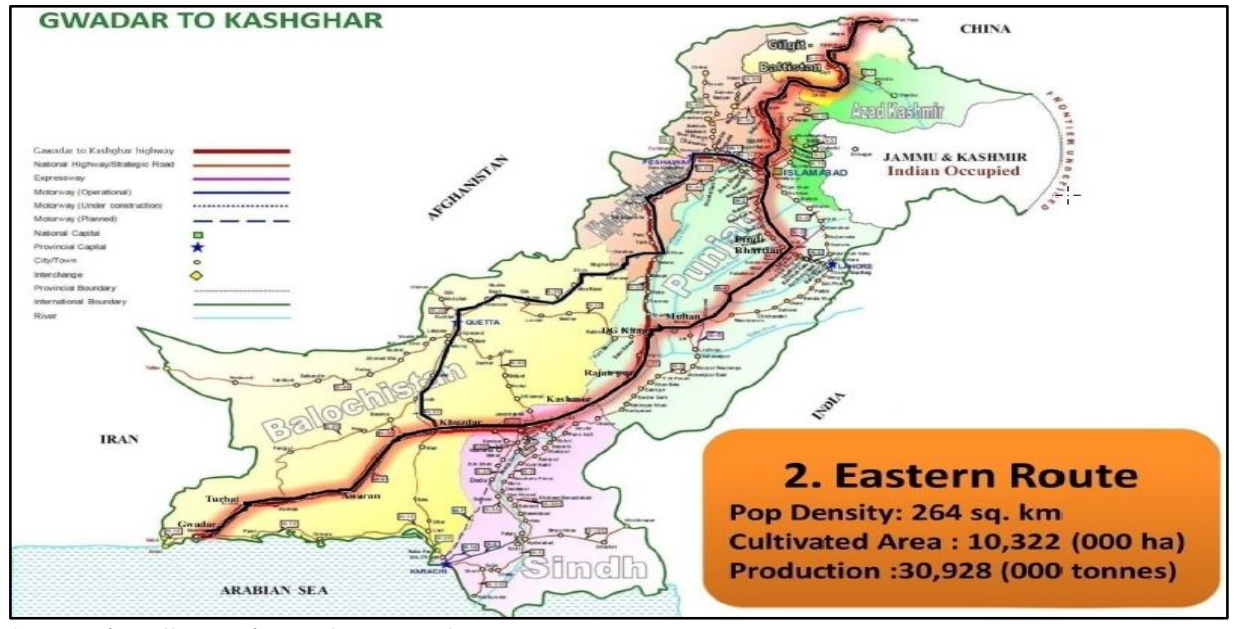

Source: http://cpecvela.com/cpec-map/

\section{Western Route}

Western Route is the one with the demolished infrastructure and deprived socioeconomic conditions. It is 2,674 KM long occupied by the areas like Attock (Punjab), DI Khan (KPK), FATA, Zhob (Baluchistan), Qila Saifullah (Baluchistan), Quetta (Baluchistan), Sorab (Baluchistan) and Panjgor (Baluchistan). It starts from FATA which is deteriorated by the on-going war on peace. War has done a gigantic damage to FATA and the victims of the collateral damage exist in great numbers. Same is the case with Baluchistan which is geographically the biggest province of Pakistan. Unfortunate peace and conflict situation and emergence of militant wings in this area have cost it a lot. Foreign involvement in the matters of this part especially India's controversies are mostly taking place there. Due to all this, the socioeconomic indicators of this part are declining. It needs more attention so that the survival becomes easier for the people of this part. Most of the unemployment, health issues, poverty and illiteracy exist over here. If CPEC passes through this route, it will eventually affect the economy of this region that will be ultimately beneficial for the people of this area. In short most of the economic and social benefits from CPEC can be availed when it is constructed on this route instead of just upgrading the already existing one. 


\section{FIGURE 4}

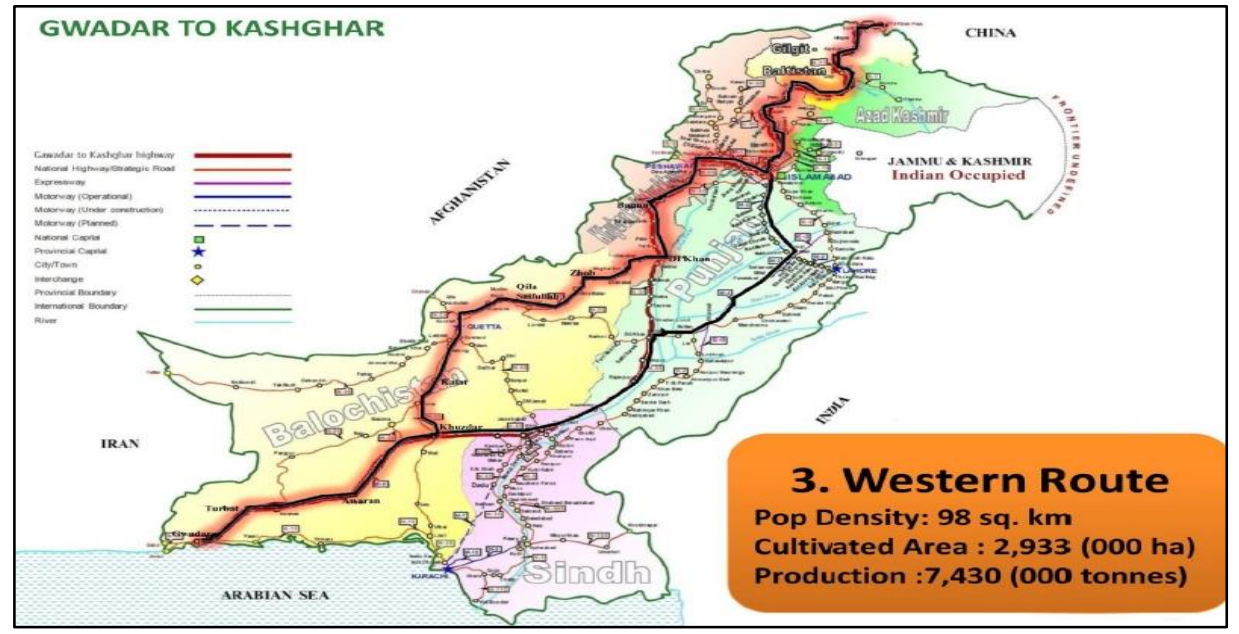

Source: http://cpecvela.com/cpec-map/

\section{Inter-Regional Development and Connectivity}

CPEC is mainly destined for promoting the regional connectivity as it will not only benefit Pakistan and China but also Afghanistan, Iran, India and the entire region. This corridor is a hopeful model for the peace, harmony cooperation and development in the future for the entire region. In the arena of globalization, CPEC holds a significant status for the economic and socioeconomic progress of not only China and Pakistan but for the other countries that lie under this region. ${ }^{10}$

Sun Weidong, the Chinese Ambassador to Pakistan, said that the 18 early harvest projects of CPEC are under smooth construction and through them about 13,500 jobs have been generated that are increasing in number. He also said that CPEC is landmark of the exemplary friendship between the twin countries and is also the reason of regional peace and prosperity. ${ }^{11}$

\section{Energy Sector Development}

Energy shortfall is one of the severe issues of Pakistan due to which a lot of potential is being wasted. Many businesses are either shut down or shifted to different countries due to the failed management in generation and distribution of energy. To address this issue, China took this challenge so seriously that out of the total cost of this Economic Corridor, $61 \%$ has been allocated to improve Pakistan's energy sector that will add 10,400 Mega-Watt electricity to the national grid by 2018 in the capacity of Early

\footnotetext{
${ }^{10}$ Quoting from the official website of CPEC created by the Government of Pakistan: http://cpec.gov.pk ${ }^{11}$ TheNation. CPEC 'great plan' of regional connectivity. March 06, 2017. http://nation.com.pk/national/06Mar-2017/cpec-great-plan-of-regional-connectivity (accessed Spetember 14, 2017)
} 
Harvest Projects of CPEC. ${ }^{12}$ Currently, Pakistan has a capacity to generate $24,830 \mathrm{MW}$, yet the shortfalls are estimated as $4500 \mathrm{MW}^{13}$ this keeps increasing and decreasing by the time. The projects under CPEC will use solar, hydro and coal resources for the energy production. In this way Pakistan aims to produce $25 \%$ of its electricity requirements by renewable energy resources. The bulk of new energy generation capacity under CPEC will be coal-based plants, with $\$ 5.8$ billion worth of coal power projects expected to be completed by early 2019 as part of the CPEC's "Early Harvest" projects. By the time all the long term projects will be operational, Pakistan is going to have energy surplus. Though, it can be analyzed better once the exact figures will be in front of us. It is obvious that the energy demand will increase multiple times when this project will be functional.

\section{Infrastructure Development}

Building and improving infrastructure is necessary for they are the motorways, railways and roads that will ensure the transportation between areas. To this time there is need of improving better access of those areas which are underprivileged to the ones with better opportunities. According to the official CPEC data there are total eight mega projects of infrastructure development on which most of the projects are based on upgrading the existing infrastructure. However, priority should be given to make new infrastructure projects other than just improving or upgrading the existing ones. Infrastructure development projects are divided into three categories; Projects in Gwadar Port and City, Roadway projects and Railways projects. In 2002 infrastructure work initiated at Gwadar Port, it includes construction of a new international airport, expansion of Gwadar Port and East Bay Expressway, which will connect Gwadar Port to the Makran Coastal Highway. In addition to this a Technical and Vocational training institute at Gwadar named Pak-China Technical and Vocational institute is under construction. The aim of this institute is to provide trainings and skills required to work at Gwadar Port to the local residents.

Pakistan's transportation infrastructure foresees major up gradation in roads and railway system. Two corridors are identified for cargo transport under CPEC: the Eastern Alignment through Sindh and Punjab which are not only dense with population but where most industries are located too and the Western Alignment that is underdeveloped and passes through sporadically populated provinces of Khyber Pakhtunkhwa and Baluchistan.

The timeworn railway system of Pakistan will also be upgraded under as part of CPEC. It includes rebuilding of the Main Line 1, 2 and 3 railways by 2020. Seventy percent of Pakistan Railways traffic is handled by Main Line 1 railway that lies between Karachi and Peshawar. A rail link over the 4,693-meter high Khunjerab Pass will also be

\footnotetext{
${ }^{12}$ Nelson, Jazib. The TFT guide to CPEC for incredibly smart people. September 02, 2016. http://www.thefridaytimes.com/tft/the-tft-guide-to-cpec-for-incredibly-smart-people/ (accessed September 26, 2016)

${ }^{13}$ Kugelman, Micheal. Pakistan's Other National Struggle: Its Energy Crisis. July 09, 2015. http://blogs.wsj.com/washwire/2015/07/09/pakistans-other-national-struggle-its-energy-crisis/ (accessed September 26, 2016)
} 
constructed under CPEC plans. It is expected that railway will be able to provide direct access for Chinese and East Asian goods to Pakistani seaports at Karachi and Gwadar by 2030 .

\section{Connectivity}

The connectivity between the countries of the region is evident through CPEC as all the neighborhood countries and beyond that the middle-east and African states are going to be directly or indirectly involved in the massive trade activity. Within the different areas of the main stakeholder countries, China and Pakistan, CPEC also ensures the interregional connectivity which is badly needed for both, Pakistan and China.

Xinjiang is the North-Western region of China that is quite ignorant compare to the other main regions in China. The reason is obviously the underdevelopment of this region due to which less employment opportunities exist. People of this region have to migrate to other areas that have better socioeconomic conditions. Due to this ignorance, separatist movement is also being run over there. Since CPEC is going to connect the Xinjiang province to Pakistan for trade, it is obviously going to create a huge impact on economic and socioeconomic condition of Xinjiang. When the different states of the country will be connected to Xinjiang through the network of motorways, railways and airports, it will create a huge difference as people will not have to move toward other regions seeking for their economic survival, in fact they will be enjoying many opportunities that CPEC will bring to the people of this region. As a plus point, another plan of developing West by China is also there working hard on improving the infrastructure and communication network.

In Pakistan, there is also a huge disparity in wealth, income and rights distribution because of the extreme underdevelopment that eventually hampers the regional connectivity. Every year heavy floods hit Pakistan in the monsoon season that destroys the deprived areas of interior Sindh and Punjab. It takes a huge chunk of time to get the news from where people need help the most due to the lack of communication. After that it takes many days to reach many of the areas due to the wrecked roads and no highways. Every year Army takes over the charge and come up with its helicopters to help those people but there are only few helicopters and the affected population size is bigger. People die of hunger and helplessness every year as no health and transportation facilities available nearby. Now with this maestro, the problem will be ebbed a high time. When the routes will be developed, they eventually have to pass through the different areas, small and big. This will ensure the existence of the smooth road network that will make the connectivity better for those who have none of it right now. When region to region access will become smooth, people will be able to benefit through it in many ways. People of the villages will be able to reach the nearby city hospital in a quick span of time when in need. Likewise, it will be easier to make, sell and barter the products between different cities which are good sign for the economy. There will be less monopoly and more competition. Prices will be sustained and inflation will be controlled. Socioeconomic uplift will be evident. 


\section{Conclusion}

CPEC is often considered as the Game Changer not only for Pakistan and China but for all the countries that lies in the region. This corridor is basically a part of new phase of globalization where the economic cooperation between countries and regions define the future of the respective economies. China, one of the fastest growing markets of the world understands this phenomenon thus it proposes $\$ 46$ billion deal with Pakistan. CPEC is often confused as just the road connecting China to Pakistan which is not the case; it is much more than just a road.

China Pakistan Economic Corridor is the beginning of an era where economic wars will define who has to flourish. One who plays it smart will stay in the competition and the one with poor strategic performance will be knocked out. China, to remain on the top of competition has some astonishing ideas and constructing economic corridors is one of them. In its One-Belt-One-Road program, it intends to build 6 corridors among which $\mathrm{CPEC}$ is one important corridor for its own startling reasons. One of the reasons is the vivacious port of Gwadar through which trade is going to make its way. Gwadar Port is that 28 meters deep water port with the berth capacity of 120 ships that when it starts to function with all its potential, it will give the record breaking trade bustle. Apart from this, the intra-regional connection with the states abiding in the region makes this project worth rejoicing. All the regional actors especially Afghanistan, Iran and Central Asian Republics applaud CPEC for the trade doors are opening for them too due to this maestro. It is a win-win game for all in the real sense except for some opponents like India and UAE, who are keen to reform its strategic policy to become able to compete with CPEC. The stance of the super power, United States has its own significance. Though, the US till this time has issued statements in favor of CPEC and its allies.

Though it is obvious that the infrastructure development through CPEC has to bring about many socioeconomic marvels for Pakistan but its route will delineate it in better way. For example, there are two ways that connects the CPEC from M1 to Gwadar, Eastern and Western routes. Eastern route is already developed and just needs some upgrading, meanwhile Western route crosses almost all the economically deprived areas that require more focus. Thus most of the socioeconomic impacts will eventually occur if the Western route is developed for it will ensure the opportunities for the ignorant masses of these areas.

Due to the lack of facilities in the interior parts of Pakistan, there is the need of proper communication and connectivity so that the transfer of news and masses from one area to another becomes convenient. CPEC, with the development of huge infrastructure, transportation and communication related projects will ensure this. This will bring a revolutionary change in socioeconomic indicators of Pakistan.

Moreover, when the early harvest and short term energy related projects will start generating the electricity, it will not only bring the lights back to the darkness but also encourage the business and investors to take interest in Pakistan's market. The employment opportunities will be generated and the development goals will become achievable shortly. Collectively, all the projects define the socioeconomic uplift as the 
project is expected to generate thousands of employment opportunities, educational and vocational institutes, healthcare facilities, clean water plants and much more. The economic development is clearly evident not only in the case of Pakistan but for China's autonomous region of Xinjiang as well.

\section{Bibliography}

December 09, 2013. http://www.hydrocarbons-technology.com/features/featurethe-10biggest-oil-consuming-countries-4141632/ (accessed September 17, 2017).

n.d. https://en.wikipedia.org/wiki/China\%E2\%80\%93Pakistan_Economic_Corridor\#Projects_ in_Gwadar_Port_and_City.

Ahmed, Prof. Dr. Hafiz Zafar, and Samar Fatima. "CPEC 2015: A Review of Proposed Opportunities and Significance." Proceedings of International Conference on CPEC Held at GC University, Lahore on December 09-10, 2015. Lahore, 2015. 134-138.

Aneja, Atul. Xi comes calling to Pakistan, bearing gifts worth \$45 billion. April 18, 2015. http://www.thehindu.com/news/international/xi-jinping-visit-to-pakistanpreview/article7114980.ece (accessed September 09, 2016).

APP. CPEC made part of China's 13th 5-year development plan: Weidong. November 23, 2015. http://www.pakistantoday.com.pk/2015/11/23/business/cpec-made-part-ofchinas-13th-5-year-development-plan-weidong/ (accessed September 26, 2016).

Butt, Dr Khalid Manzoor, and Anam Abid Butt. "Impact of CPEC on Regional and Extra-Regional Actors: Analysis OF Benefits and Challenges." Proceedings of International Conference on CPEC Held at GC University, Lahore on December 09-10, 2015. Lahore, 2015. 128-133.

Cheema, Zumra Nawaz. Geostrategic importance of China-Pakistan Economic Corridor. May 2015, 2015. http://foreignpolicynews.org/2015/11/25/geostrategic-importance-ofchina-pakistan-economic-corridor/ (accessed September 17, 2017).

Ebrahim, Zofeen T. China's new silk road: What's in it for Pakistan? April 20, 2015. http://www.dawn.com/news/1177116 (accessed September 26, 2016).

Idrees, Insha. "China-Pakistan Economic Corridor: Changing Scenario of Socioeconomic and Human Development." Proceedings of International Conference on CPEC Held at GC University, Lahore on December 09-10, 2015. Lahore, 2015. 145-150.

Johnson, Keith. China Is the New Power Broker in the Persian Gulf. March 26, 2015. http://foreignpolicy.com/2015/03/26/chinas-thirst-oil-foreign-policy-middle-east-persiangulf/ (accessed September 26, 2016). 
Khan, Azam. CPEC: invigorating the national maritime sector. January 12, 2016. https://www.thenews.com.pk/print/89601-CPEC-invigorating-the-national-maritimesector (accessed September 26, 2016).

Kugelman, Micheal. Pakistan's Other National Struggle: Its Energy Crisis. July 09, 2015. http://blogs.wsj.com/washwire/2015/07/09/pakistans-other-national-struggle-itsenergy-crisis/ (accessed September 26, 2016).

masood, Talat. China's landmark investments in Pakistan. April 21, 2015. http://tribune.com.pk/story/873627/chinas-landmark-investments-in-pakistan/ (accessed September 26, 2016).

Nelson, Jazib. The TFT guide to CPEC for incredibly smart people. September 02, 2016. http://www.thefridaytimes.com/tft/the-tft-guide-to-cpec-for-incredibly-smart-people/ (accessed September 26, 2016).

Shah, Saeed. 20 April, 2015. http://www.wsj.com/articles/chinas-xi-jinping-set-tolaunch-investment-deal-in-pakistan-1429533767 (accessed September 26, 2016).

-. China's Xi Jinping Launches Investment Deal in Pakistan. 20 April, 2015. http://www.wsj.com/articles/chinas-xi-jinping-set-to-launch-investment-deal-in-pakistan1429533767 (accessed September 26, 2016).

-. Chinese-Pakistani Project Tries to Overcome Jihadists, Droughts and Doubts. April 10, 2016. http://www.wsj.com/articles/big-chinese-pakistani-project-tries-to-overcomejihadists-droughts-and-doubts-1460274228 (accessed September 26, 2016).

The 10 biggest oil consuming countries. December 09, 2013. http://www.hydrocarbonstechnology.com/features/featurethe-10-biggest-oil-consuming-countries-4141632/ (accessed September 17, 2017).

TheNation. CPEC 'great plan' of regional connectivity. March 06, 2017. http://nation.com.pk/national/06-Mar-2017/cpec-great-plan-of-regional-connectivity (accessed Spetember 14, 2017).

Shah, S. (2015, 20 April). Retrieved September 26, 2016, from http://www.wsj.com/articles/chinas-xi-jinping-set-to-launch-investment-deal-in-pakistan$\underline{1429533767}$

(n.d.). Retrieved from https://en.wikipedia.org/wiki/China\%E2\%80\%93Pakistan_Economic_Corridor\#Projects_ in_Gwadar_Port_and_City 